International Journal of Business Management and Economic Review

Vol. 4, No. 02; 2021

ISSN: 2581-4664

\title{
THE EFFECT OF WORK FROM HOME DURING THE COVID-19 PANDEMIC ON WORK-LIFE BALANCE AND ITS IMPACT ON EMPLOYEE PERFORMANCE OFACEH COMMUNICATION, INFORMATICS AND ENCODING OFFICE
}

\author{
*Sheila De Tiroina, Mahdani, Sulaiman \\ Management Department, UniversitasSyiah Kuala, Indonesia \\ http://doi.org/10.35409/IJBMER.2021.3240
}

\begin{abstract}
This study intends to examine the effect of work from home during the Covid-19 pandemic on work-life balance and its effect on the employee performance of the Aceh Communication, Informatics And Enoding Office (Diskominfo). This research is a confirmatory research. The population taken was employees at the Aceh Diskominfo who received a direct impact on the work from home policy during the Covid-19 pandemic, totaling 101 people. Data were collected using a questionnaire and measured using a Likert scale. Data were analyzed using Structural Equation Modeling (SEM). The test results on the Aceh Diskominfo employees show that work from home significantly affects employee performance, work from home significantly affects employee work-life balance, work-life balance significantly affects employee performance, and work from home significantly affects employee performance through work-life balance. These findings show that in the Covid-19 pandemic, work from home remains a determinant of employee performance, even though conditions are different from when not facing the Covid-19 pandemic. Work-life balance also acts as a partial mediator, which can be influenced by work from home and affect employee performance. Researchers can then develop the findings of this proven model, by adding variables such as competence in information technology and talent management which are needed during the Covid-19 pandemic, to be more practical in carrying out work in organizations/companies
\end{abstract}

Keyword:Work From Home, Work-Life Balance, Employee Performance, Covid 19.

\section{INTRODUCTION}

The Covid-19 pandemic has affected the work system of organizations around the world, especially Indonesia. On March 15, 2020, President Joko Widodo appealed to minimize the spread of the Covid-19 virus, people are asked to work, study and worship from home. When doing work from home (work from home), many employees feel a balance in carrying out their work and social life (work-life balance)(Mustajab et al., 2020). They can divide their time between doing their job and their social life. For male employees, work-life balance is very dominant, they can do a good job and the remaining time can be used to live a social life such as chatting, interacting with family and colleagues even though it can only be done through social media or other communication media without face to face. directly. However, this does not apply to married female employees, work-life balance cannot be felt because they have difficulty 


\section{International Journal of Business Management and Economic Review}

Vol. 4, No. 02; 2021

ISSN: 2581-4664

dividing their time between work and social life. This is because married women have a greater obligation to take care of the household. So after they do office work at home, they generally have to complete household tasks such as caring for children, cleaning the house, and so on.

(Weerasinghe \& Jayawardana, 2020)stated that there are several ways that can be done to improve employee performance, one of which is by achieving a balance between family life and work (work-life balance). Work from home will have many positive impacts on employees when they get a balance and this will greatly contribute to increasing employee morale and can also become an organizational culture in the future. However, the implementation of the work from home also has a negative impact on the performance of the employees themselves where employees who work at home spend more time or do not have a proportional percentage of their time in carrying out family and work responsibilities.

The ineffective performance of the employees of the Aceh Communication, Informatics and Encoding (Diskominfo) office as a government agency in Aceh has an impact on the performance of the office as stated in its 2020 Performance Report (LAKIP). There was a decrease in the achievement of performance realization wherein 2019 the achievement of performance realization reached $92 \%$ but in 2020 there was a significant decline where the realization of the performance only reached $77 \%$ of the target set at the beginning of the year.

In a direct interview that the authors conducted with the Head of the Law, Personnel and Administration subdivision at the Aceh Diskominfo, stated that the low 2020 performance achievement was due to several problems including adjustment of working hours, timeliness in completing tasks and comfort at work. With the aforementioned problems such as adjusting working hours, timeliness in completing tasks, and comfort at work, it shows that the work-life balance is still low at the Aceh Diskominfo. The low work-life balance in Aceh Diskominfo resulted in delays in completing work, decreased organizational stability, decreased employee performance and the organization was unable to provide maximum service.

Based on the above phenomena, researchers conducted a preliminary survey of 20 employees of the Aceh Diskominfo regarding employee performance, work-life balance, and work from home. From the results of the initial survey, it was found that the three variables that the researchers used in this study were all still in poor condition where the average value obtained by performance was 3.34, the average work-life balance was 3.36 and the work from home average value was 3. , 35. These values on the Likert scale are still in poor / not good condition. From the results of this initial survey, it was also known that the performance of Aceh Diskominfo employees was not optimal. More was caused by personal problems, not skilled in planning time when working from home.

Departing from the phenomena and survey results mentioned above, in order to improve employee performance and to produce a concrete understanding of the effect of work from home on work-life balance and its impact on the performance of the Aceh Diskominfo.

\section{LITERATURE STUDY}

\section{Employee Performance}

In the Government Regulation of the Republic of Indonesia No. 30 of 2019 concerning the performance appraisal of civil servants (PNS), explained that performance is the work achieved by every civil servant in an organization/unit following the employee performance system and work behavior. While(Hasibuan, 2016)mentioned performance as an effort to manage 


\section{International Journal of Business Management and Economic Review}

Vol. 4, No. 02; 2021

ISSN: 2581-4664

competencies carried out by the organization systematically and continuously so that it has the level of performance expected by the organization, namely being able to provide optimal contributions, so as to achieve organizational goals. (Suwanto \& Priansa, 2016)explained the work performance is the result achieved by a person according to prevailing standards within a certain period. Concerning work, behavior, and actions In the current Covid 19 Pandemic era, work-life balance and work from home are factors that can also affect employee performance in an organization.

In this study, employee performance measurement uses indicators as stated in Government Regulation No. 30 of 2019, namely aspects of service orientation, commitment, work initiatives, cooperation, and leadership. This indicator was chosen because the respondents in this study were civil servants. Performance appraisal is a series of processes in the PNS Performance Management System.

\section{Work-Life Balance}

Work-life balance is a form of balance that occurs in a person's life where they do not forget their duties and obligations at work without having to neglect all aspects of their personal life.(McDonald \& Bradley, 2005)stated that work-life balance is the level of satisfaction associated with multiple roles in a person's life. Meanwhile(Fisher, Bulger, \& Smith, 2009)disclosed worklife balance as an effort made by individuals to balance two or more roles that are undertaken. When a person experiences a work-life balance in his life, it can be ascertained that the individual is very satisfied with the situation he is living in.

In this study, the measurement of work-life balance uses the indicators disclosed by(McDonald \& Bradley, 2005)namely decision making, family responsibility, and timely completion of tasks. This indicator was chosen because it fits the model and conditions in the field where this research was conducted.

\section{Work From Home}

Work from home is a conceptualization process in which a person can carry out the responsibilities assigned to him by obtaining the comfort of home. Work from home provides flexibility in working(Reddy \& Ramasamy, 2018). Working from home is beneficial for maintaining work-life balance and at the same time benefiting the organization in completing work. Nowadays most organizations offer them a work from home option. By working from home employees can gain freedom of access to certain jobs, through less distraction from the office and have more communication time(Baruch, 2003).

With an increasing number of organizations adopting the work from home concept and using the home as a work destination, it is clear that this will increase retention. This results in increased motivation with reduced stress and can also benefit the organization due to decreased usage of organizational facilities. Employees working from home can do office work as well as tasks needed from home simultaneously. Allowing to work from home encourages a better worklife balance and can lead to improved health and well-being.

During the Covid 19 pandemic and in efforts to prevent its spread, the work from home option was the best alternative for all organizations. However, this certainly has positive and negative impacts both on the employee side and the organization itself. As disclosed by(Dua\& Hyronimus, 2020)Work from home has an influence on work-life balance, which can cause 


\section{International Journal of Business Management and Economic Review}

Vol. 4, No. 02; 2021

ISSN: 2581-4664

conflict between work life and family interests. But on the other hand, as has been stated by previous researchers such as(Baruch, 2003)and(Reddy \& Ramasamy, 2018)work from home can also have a positive impact on employees and the organization itself. The practice of work from home has long been practiced by developing organizations since the 1970s. This practice is carried out as an effort to reduce traffic congestion. However, this practice is carried out in normal conditions, not because of a pandemic as it is today.

In this study, the measurement of work from home uses indicators as expressed by(Nakrošienè, Bučiūnienè, \& Goštautaitè, 2019)namely skilled in planning time, the possibility to work at productive times, and support from superiors. This indicator was chosen because it fits the model being built and is suitable for the conditions in the field where the research was carried out.

\section{Research Hypothesis}

Based on the discussion of previois theories and research problems, this study develops the hypotheses as follows:

H1: work from home significantly affects employee performance

$\mathrm{H} 2$ : work from home significantly affects work-life balance

H3: work-life balance significantly affects employee performance

$\mathrm{H} 4$ : work from home significantly affects performance through work-life balance

\section{RESEARCH METHOD}

This study is a confirmatory type of research. The population taken were employees at the Aceh Diskominfo who received a direct impact on the work from home policy during the Covid19 pandemic, totaling 101 employees. Data were collected using a questionnaire and using a Likert scale. Data were analyzed by Structural Equation Modeling (SEM) using the AMOS application.

Mathematically, the research model can be stated as follows:

$\eta_{1}=\gamma_{1.1} \xi_{1}$

$\eta_{2}=\gamma_{2.1} \xi_{1}+\beta_{2.1}+\xi$

or

Work-life balance $\quad=\gamma_{1.1}$ work from home

Performance $=\gamma_{2.1}$ work from home $+\beta_{21}$ work-life balance $+\xi_{2}$

Where:

$\gamma \quad=$ The magnitude of the exogenous variables in influencing the endogenous variables

$\beta \quad=$ The magnitude of endogenous variables in influencing endogenous variables

$\xi \quad=$ The magnitude of the error vector for the structural relationship between variables.

Hypothesis testing was based on the criteria for grouping variable categories based on the average score $(\mathrm{X})$ as shown earlier, where:

- If $X<3.41$ then Howill be accepted and Ha will berejected.

- If $X \geq 3.41$ then Howill be rejected and Hawill be accepted

The first, second, andthird hypotheses were said to be the verification hypotheses that consider the direct influence between variables. Furthermore, testing the fourth hypothesis 
International Journal of Business Management and Economic Review

Vol. 4, No. 02; 2021

ISSN: 2581-4664

placed work-life balance as an intervening variable of work from home with the performance of the Aceh Diskominfo employees. Hypothesis testing led to opinions(Baron \& Kenny, 1986)about testing theintervening effect.

\section{RESULT AND DISCUSSION Direct Hypothesis Testing}

The structural model analysis that explains the effect test between variables is presented in the following path diagram:

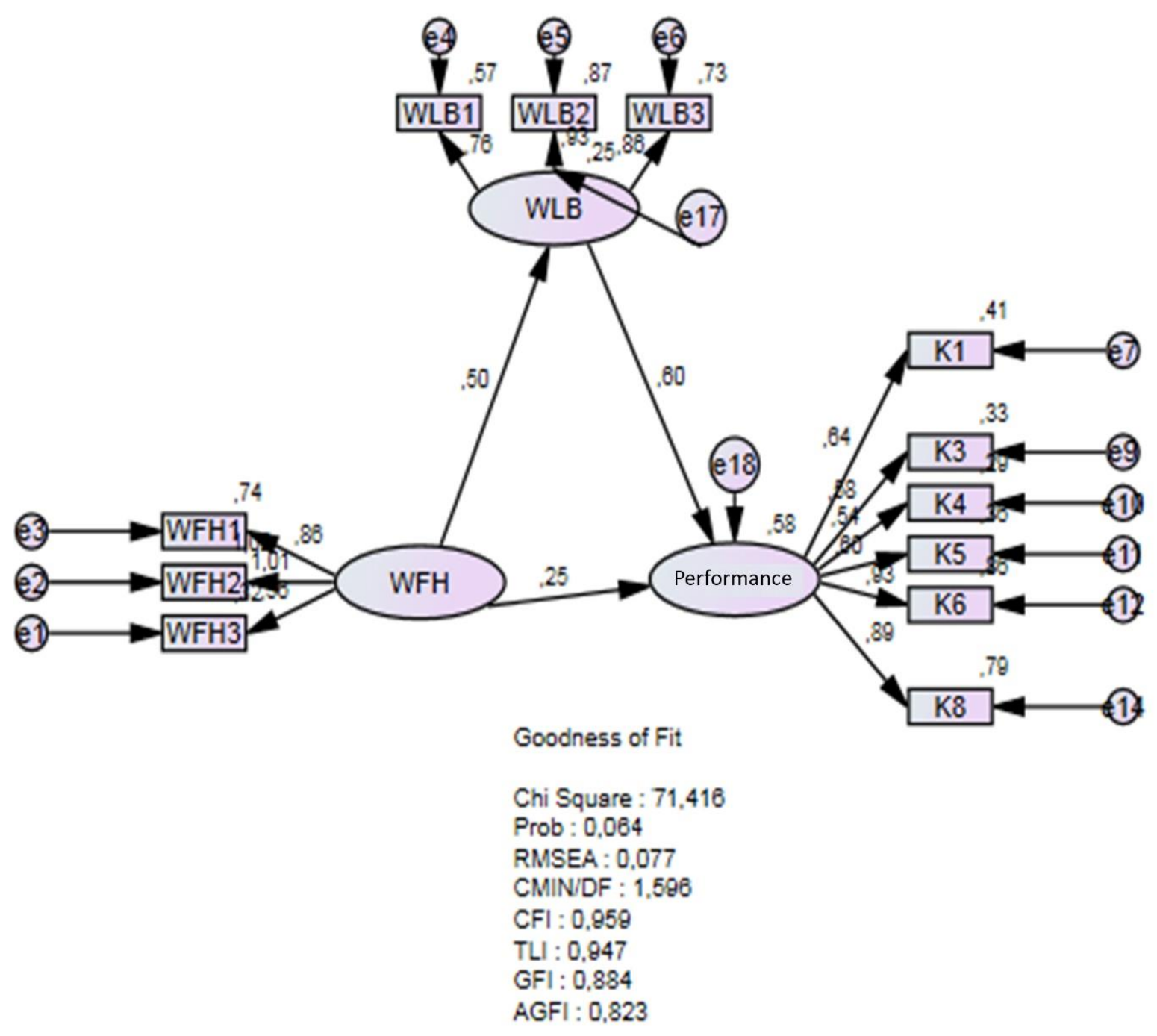

Figure 1.Test Result

The test results of the full model for testing the direct effect hypothesis after fulfilling the SEM assumptions are more clearly shown in the following table: 
International Journal of Business Management and Economic Review

Vol. 4, No. 02; 2021

ISSN: 2581-4664

Table 1. Hypothesis Test Results

\begin{tabular}{|lrl|lrrr|}
\hline & & & Estimate & S.E. & C.R. & P \\
\hline Work-Life Balance & $<---$ & Work From Home & .431 & .106 & 4.048 & $* * *$ \\
Performance & $<--$ & Work-Life Balance & .449 & .095 & 4.727 & $* * *$ \\
Performance & $<---$ & Work From Home & .163 & .063 & 2.586 & .010 \\
\hline
\end{tabular}

Source: Primary data, 2020 (processed)

Based on the results of SEM analysis in Table 2 and statistical equations (1) and (2), the following results can be formulated:

Work-Life Balance $=0,431$ Work From Home

Performance $=0.163$ Work From Home +0.449 Work-Life Balance

From the test findings in Table 2, it can be explained as follows:

1. H1: The results of testing the effect of work from home on employee performance resulted in a CR value of 2.586 with a significance level of 0.01 . So it can be concluded that work from home can significantly affect employee performance improvement. This indicates that the higher the level of work from home, the better employee performance will be. The magnitude of the influence of work from home on employee performance is 0.163 or $16.3 \%$. This indicates that the better work from home will have a positive and significant impact on improving employee performance.(Bloom, Liang, Roberts, \& Ying, 2015)in his research found that there was a significant increase in the performance of those working from home. Where workers who worked from home work longer than their period of working hours, and only a few workers who worked less because of rest and illness. working from home was also reported to have significantly higher job satisfaction and psychological attitude scores.

2. H2: The results of testing the effect of work from home on employee performance resulted in a CR value of 4.727 with a significance level of 0.000 . So it can be concluded that work from home can significantly affect employee performance improvement. This indicates that the better work from home will have a positive and real effect on increasing work-life balance. The magnitude of the effect of work from home on work-life balance is 0.431 or $43.1 \%$. This indicates that the better work from home will have a positive and significant effect on increasing work-life balance. The results of this study are in line with the research conducted by(Krasulja, Blagojevic, \& Radojevic, 2015)there is a positive effect of work from home on work-life balance. Work from home can certainly represent a good perspective when it comes to solving work-life balance problems. With the creation of a work-life balance, employees can feel the flexibility to manage the time during the day, the possibility to care for children and families, and a higher level of relaxation. (Duxbury \& Higgins, 2002)said that work from home has a positive effect on the harmony of family life because all time is spent on children, siblings, home environment, and other relationships and this has an impact on work-life balance. Work from home can also increase conflict between work and family if workers spend more time at home or a disproportionate 
International Journal of Business Management and Economic Review

Vol. 4, No. 02; 2021

ISSN: 2581-4664

percentage of their time is spent on work and family.

3. H3: The results of testing the effect of work-life balance on employee performance resulted in a CR value of 4.578 with a significance level of 0.000 . So it can be concluded that worklife balance can significantly affect employee performance improvement. This indicates that the higher the level of work-life balance, the better employee performance will be. The magnitude of the effect of work from home on work-life balance is 0.449 (44.9\%). This indicates that the better work from home will have a positive and significant effect on increasing work-life balance. In research conducted by(Saina, Pio, \& Rumawas, 2016)It is known that there is a positive effect of work-life balance on improving employee performance. The indicator in this research is to determine the working hour commitment between the organization and employees. To achieve satisfaction with the work-life balance, the organization acts as a supporting factor that provides fair rules and policies, but what is most important is the attitude of the employees themselves in aligning their commitments with their family and their professional life, both in terms of time, communication and direct involvement.

\section{Indirect Hypothesis (Mediation) Testing}

The result of testing the indirect hypothesis (mediation) is described below:

1. H6: The Effect of Work From Home on Employee Performance through Work-Life Balance as can be seen in the following figure:

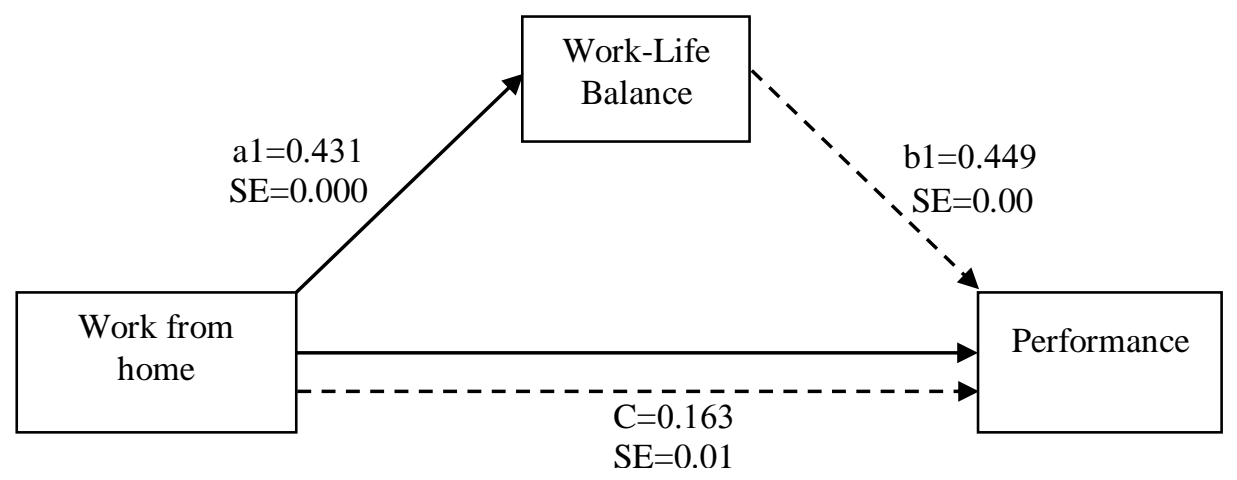

Figure 2.Results of Hypothesis 4 (Mediation Effect)

Based on Figure 3, it is obtained the path coefficient of work from home with work-life balance, the path coefficient value is 0.431 ; while the work-life balance path coefficient on employee performance is 0.449 . The path coefficient between work from home and employee performance is 0.163 . Because the effect of work from home on employee performance is significant at $\alpha=5 \%$, the effect of work from home on work-life balance is significant at $\alpha=5 \%$, and the effect of work-life balance on employee performance is also significant at $\alpha=5 \%$, it can be concluded that work-life balance acts as a variable that mediates the relationship between work from home and employee performance. The 
International Journal of Business Management and Economic Review

Vol. 4, No. 02; 2021

ISSN: 2581-4664

mediation role played by job satisfaction is partially mediating.

\section{CONCLUSION}

The test results on the Aceh Diskominfo employees prove that Work from home has a significant effect on employee performance. This shows that work from home can be an alternative to a new work system and can be implemented in employee work systems, especially in the object of research. Work from home also significantly affects work-life balance. This finding prove that work from home can increase the work-life balance of employees. In addition to being able to carry out office work well, employees can also carry out their personal lives well so that they can achieve a balance in their work life. Work-life balance also significantly affects employee performance which explains that the higher the level of work-life balance felt by employees, the more employee performance can be increased.

Furthermore, work from home has also been shown to affect employee performance through work-life balance, which shows that work-life balance has a role as a variable that mediates the relationship between work from home and employee performance. The findings also show that work-life balance plays a role in this employee performance model as a partial mediator. This proves that in the Covid-19 pandemic, work from home remains a determinant of employee performance, even though conditions are different from when not facing the Covid-19 pandemic. The further researchers can then develop the findings of this proven model, by adding variables such as competence in information technology and talent management which are very much needed during the Covid-19 pandemic, to be more practical in carrying out work in organizations/companies.

Several recommendations are mapped in this research, especially for practitioners on the object of research. Work from home is an alternative to a new work system during the Covid-19 pandemic. In order for work from home to be carried out optimally, cooperation from all parties is required. Support from superiors is the most important thing for the creation of good employee performance at the Aceh Diskominfo. It takes a commitment to each employee in order to be able to separate work life and personal life. Even though the work-life balance of employees at Diskominfo Aceh is good, it should be maintained so that there will be an increase in realization in the future in order to improve the overall employee performance. Lack of leadership ability to motivate employees is often a problem in the work environment, andthis is also found within the Aceh Diskominfo. It takes good faith from local leaders to be able to do as little as possible trying to motivate employees so that closeness between leaders and subordinates can be created and lead to an increase in the performance of the employees of the Aceh Diskominfo.

\section{REFERENCES}

Baron, R. M., \& Kenny, D. A. (1986). The moderator-mediator variable distinction in social psychological research: Conceptual, strategic, and statistical considerations. Journal of Personality and Social Psychology, 51(6), 1173-1182. https://doi.org/10.1037//00223514.51.6.1173

Baruch, Y. (2003). The status of research on teleworking and an agenda for future research. International Journal of Management Reviews, 3(2), 113-129. https://doi.org/https://doi.org/10.1111/1468-2370.00058

Bloom, N., Liang, J., Roberts, J., \& Ying, Z. J. (2015). Does Working from Home Work? 


\section{International Journal of Business Management and Economic Review}

Vol. 4, No. 02; 2021

ISSN: 2581-4664

Evidence from a Chinese Experiment. The Quarterly Journal of Economics, 130(1), 165-218. https://doi.org/10.1093/qje/qju032

Dua, M. H. C., \& Hyronimus. (2020). Pengaruh Work From Home Terhadap Work-Life Balance Pekerja Perempuan Di Kota Ende. Jurnal Ilmiah Manajemen Bisnis Dan Inovasi Universitas Sam Ratulangi, 7(2), 247-258. https://doi.org/https://doi.org/10.35794/jmbi.v7i2.30266

Duxbury, L., \& Higgins, C. (2002). Telework: A primer for the millennium introduction. In C. L. Cooper \& R. J. Burke (Eds.), The new world of work: Challenges and opportunities. Oxford, UK: Blackwell Publishers Ltd.

Fisher, G. G., Bulger, C. A., \& Smith, C. S. (2009). Beyond Work and Family: A Measure of Work/Nonwork Interference and Enhancement. Journal of Occupational Health Psychology, 14(4), 441-456. https://doi.org/10.1037/a0016737

Hasibuan, M. S. (2016). Buku Manajemen Sumber Daya Manusia (Revisi). Jakarta: Bumi Aksara.

Krasulja, N., Blagojevic, M. V., \& Radojevic, I. (2015). Working from home as alternative for acheving work-life balance. Ekonomika, 61(2), 131-142. https://doi.org/10.5937/ekonomika1502131K

McDonald, P., \& Bradley, L. M. (2005). The Case for Work-Life Balance: Closing the Gap Between Policy and Practice. Australia: Hudson Global Resources (Aust.) Pty Limited.

Mustajab, D., Bauw, A., Rasyid, A., Irawan, A., Akbar, M. A., \& Hamid, M. A. (2020). Working From Home Phenomenon as an Effort to Prevent COVID-19 Attacks and Its Impact on Work Productivity. The International Journal of Applied Business, 4(1), 13-21. https://doi.org/http://dx.doi.org/10.20473/tijab.V4.I1.2020.13-21

Nakrošienè, A., Bučiūnienè, I., \& Goštautaitè, B. (2019). Working from home: characteristics and outcomes of telework. International Journal of Manpower, 40(1), 87-101. https://doi.org/https://doi.org/10.1108/IJM-07-2017-0172

Reddy, L. S., \& Ramasamy, K. (2018). introspection Of Work-From- Home In It Industry. International Journal of Advance and Innovative Research, 5(4), 522-535.

Saina, I. V., Pio, R. J., \& Rumawas, W. (2016). Pengaruh Worklife Balance dan Kompensasi Terhadap Kinerja Karyawan Pada PT PLN (Persero) Wilayah Suluttenggo Area Manado. Jurnal Administrasi Bisnis, 4(3), 1-9. https://doi.org/https://doi.org/10.35797/jab.4.3.2016.12892.\%25p

Suwanto, \& Priansa, D. J. (2016). Manajemen SDM dalam Organisasi Publik dan Bisnis. Bandung: Alfabeta.

Weerasinghe, T. D., \& Jayawardana, A. (2020). Flex-Work and Work-Life Balance: Effect of Role Conflicts and Work-Life Support Organizational Culture. Sri Langka Journal of Management, 24(2), 49-76. https://doi.org/https://doi.org/ 10.33939/SLJM.24.02.03.2019 